\title{
Protest Voting dan Abstention dalam Pilkada Calon Tunggal: Kasus Pilkada Serentak 2018
}

\author{
Mahpudin \\ Departemen Politik Pemerintahan \\ Universitas Gadjah Mada \\ Mahpudinapud3@gmail.com
}

\begin{abstract}
ABSTRAK
Tulisan ini membahas tentang dinamika partisipasi pemilih dalam konteks pemilihan kepala daerah dengan satu pasangan calon. Politik elektoral yang hanya diikuti oleh satu pasangan calon menyebabkan munculnya kotak kosong untuk memastikan kontestasi tetap ada. Kotak kosong menjadi pilihan alternatif bagi pemilih yang tidak puas dengan calon atau kecewa dengan kondisi politik yang ada. Karena itu, dalam setting pemilu lokal dengan calon tunggal telah memunculkan fenomena protest voting dan abstenstion. Artikel ini berargumen bahwa meskipun mayoritas daerah dimenangkan oleh pasangan calon, tetapi apabila dianalisa lebih detail, kemenangan pasangan calon pada beberapa daerah tidak signifkan dibandingkan dengan presentase perolehan suara akumulasi dari protest voting dan abstention. Hal ini merefeleksikan bahwa tidak semua pasangan calon yang menang ditopang oleh basis legitimasi yang kuat.
\end{abstract}

\section{Kata Kunci: Partisipasi pemilih, Protest Voting, Abstention, Pemilu Lokal}

\section{Pendahuluan}

Artikel ini membahas tentang dinamika partisipasi pemilih dalam Pilkada dengan satu pasangan calon. Bagaimana protest voting dan abstention berkerja dalam konteks pilkada calon tunggal adalah dua pertanyaan inti yang ingin dijawab dalam artikel ini. Isu tentang calon tunggal menjadi menarik untuk ditelaah lebih lanjut sebab dapat dikatakan menjadi diskursus politik yang relatif baru dalam dinamika politik elektoral di tingkat lokal. Pilkada calon tunggal mulai muncul ke permukaan sejak diperkenalkannya desain pilkada serentak. Selama tiga kali periode Pilkada yang sudah diselenggarakan (tahun 2015, 2017, 2018), eksistensi calon tunggal dapat ditemukan di berbagai 
daerah. Pelaksanaan pilkada serentak tahun 2018 misalnya setidaknya terdapat 18 daerah yang hanya memiliki satu pasangan calon.

Kontestasi elektoral dalam Pilkada calon tunggal tentu berbeda dengan pilkada pada umumnya yang memiliki minimal dua pasangan calon. Dalam konteks pilkada calon tunggal, dimunculkan istilah "kotak kosong". Kehadiran kotak kosong merupakan respon terhadap munculnya calon tunggal di berbagai daerah yang ditandai oleh kuatnya dominasi calon tunggal yang didukung oleh mayoritas partai politik (Romli, 2018). Kemunculan calon tunggal telah melunturkan prinsip kontestasi dan partisipasi dalam pemilu. Padahal, kontestasi dan partisipasi adalah prinsip penting dalam demokrasi minimalis ala Schumpeterian. Karena itu, kotak kosong dihadirkan berhadapan dengan calon tunggal agar kontestasi dan partipasi dalam pemilu tetap ada. Hal ini sejalan dengan pandangan Robert Dahl (1973) yang menyebut bahwa kontestasi dan partisipasi menjadi basis utama sebagai prasyarat demokrasi. Bagi Dahl, demokrasi yang baik menghendaki adanya kontestasi dan partisipasi yang tinggi dalam politik elektoral.

Artikel ini tidak hendak membahas dimensi kontestasi elektoral antara calon tunggal versus kotak kosong sebagaimana ditemukan pada sejumlah literatur (Lay, et al., 2017; Hikmania, 2018; Buhanuddin, 2018; Widyasari, et al., 2019). Artikel ini fokus pada dimensi partisipasi, terutama partisipasi pemilih (voters turnout). Partisipasi pemilih menjelaskan seberapa besar pemilih datang ke tempat pemungutan suara (TPS) untuk menggunakan hak pilihnya di hari pemilihan (on election day). Hal ini terkait dengan presentase suara termasuk suara tidak sah (IDEA, 2016).

Dimensi partisipasi dipilih sebagai objek bahasan karena dilandasi oleh argumen bahwa partisipasi pemilih dalam Pilkada calon tunggal dihiasi oleh 
hadirnya fenomena protest voting dan abstention. Hal ini tidak lepas dari asumsi bahwa pemilih yang memilih kotak kosong dibandingkan pasangan calon merupakan bentuk ekspresi ketidakpuasan terhadap sistem politik yang ada, terutama ketidaksukaan terhadap figur pasangan calon yang ada. Kotak kosong menjadi alternatif pilihan sebagai simbol perlawanan terhadap pasangan calon. Sementara, pemilih yang sama sekali tidak menggunakan hak pilihnya di hari pemilihan adalah bentuk abstention. Mereka tidak memilih keduanya, baik pasangan calon maupun kotak kosong. Oleh karena itu, paling tidak terdapat tiga kemungkinan yang menjelaskan partisipasi pemilih dalam pemilu calon tunggal, yaitu pilihan untuk memilih pasangan calon, kotak kosong atau abstein. Artikel ini ingin mendeskripsikan dan menganalisa tren presentase perolehan suara dari tiga pilihan tersebut di seluruh daerah yang mengkontestasikan antara pasangan calon dan kotak kosong pada Pilkada serentak tahun 2018.

Struktur artikel ini dibangun melalui berberapa pokok pembahasan. Bagian pertama akan meletakan konsep protest voting dan abstention sebagai bagian yang tidak terpisahkan dari diskursus partisipasi pemilih (voters turnout). Konsep ini digunakan sebagai pisau analisa dalam menganalisa pola partisipasi pemilih pada pilkada calon tunggal. Bagian kedua menguraikan perjalanan politik elektoral di daerah yang berakhir pada hadirnya kontestasi politik antara calon tunggal dan kotak kosong. Uraian ini menjadi penting untuk menjelaskan konteks kemunculan calon tunggal dan kotak kosong dan bagaimana keduanya bekerja dalam logika kekuasaan. Bagian ketiga adalah pembacaan sekaligus analisa terhadap data tentang partisipasi pemilih dalam Pilkada calon tunggal dengan spesifik pada pilkada serentak tahun 2018. Terakhir, artikel ini menghadirkan pemaparan lebih detail terkait protest voting 
dan abstention dengan segala perdebatannya. Bahasan pentingnya memperkuat eksistensi kotak kosong akan menjadi bagian penutup pada arikel ini.

\section{Tinjauan Pustaka}

Partispasi pemilih atau dikenal dengan voters turnout merupakan salah satu indikator yang sangat krusial dalam demokrasi elektoral. Hal ini berangkat dari sebuah pemahaman bahwa pemilu sebagai legitimasi formal bagi pemerintahan yang berkuasa. Tingkat legitimasi ini diukur dari seberapa besar presentase partisipasi warga negara dalam pemilu. Semakin besar partisipasi pemilih semakin besar legitimasi dan kepercayaan warga negara terhadap pemerintahan yang terpilih dari pemilu. Sebaliknya, partisipasi pemilih yang rendah sering dikaitkan dengan hadirnya krisis legitimasi dan kepercayaan (IDEA, 2016; Delwit, 2012). Partisipasi pemilih sendiri dimaknai sebagai seberapa besar pemilih datang ke tempat pemungutan suara (TPS) untuk menggunakan hak pilihnya di hari pemilihan (on election day). Hal ini terkait dengan presentase suara termasuk suara tidak sah (IDEA, 2016).

Namun, dalam konteks partisipasi pemilih, terdapat dinamika politik yang berkembang didalamnya khususnya terkait ketersediaan pilihan yang ada dalam pemilu. Tidak semua partai atau kandidat disukai oleh pemilih sehingga hal tersebut memicu munculnya tindakan pemilih untuk melakukan protes atau abstain dalam pemilu. Protes atau abstain sebagai sebuah pilihan politik merupakan keniscayaan dalam politik elektoral.

Pada dasarnya, protest voting dan abstention sering dikaitkan dengan ekspresi kekecewaan dan ketidakpuasaan pemilih terhadap pilihan yang ada (Kang, 2004; Kselman \& Niou, 2014; Rosenstone, et al, 1996). Protest voting merujuk pada tindakan pemilih memilih partai atau kandidat lain meski bukan pilihan murni mereka sebagai bentuk kritik dan ketidakpuasan pemilih terhadap partai atau kandidat yang menjadi preferensi utama mereka (Rosenstone, et al, 1996). Protest voting juga dapat dimaknai sebagai kondisi ketika pemilih menggunakan hak pilihnya memilih partai atau kandidat tertentu bukan karena pemilih menyukai partai atau kandidat tersebut tetapi dikarenakan tidak ada alternatif pilihan lain yang tersedia dalam pemilu (Kang, 2004).

Selain protest voting, dalam situasi ketidakpuasan pemilih terhadap pilihan yang ada, pemilih dapat mengambil sikap abstention yaitu menarik diri 
dari pemilu dengan tidak memberikan suara mereka sama sekali terhadap partai atau kandidat yang tersedia (Klesman \& Niou, 2014; Kang, 2004). Hal ini dimungkinkan terjadi sebab pemilih merasa tidak mendapatkan manfaat apapun apabila menggunakan suara mereka saat hari pemungutan suara. Negara yang memberikan kebebasan hak memilih memiliki potensi tingkat abstention lebih tinggi ketimbang negara yang menerapkan hukum wajib memilih kepada warga negaranya seperti ditemukan di Australia, Belgia, Italia, Bolivia. Negara-negara tersebut memberikan sanksi tertentu apabila warga negara tidak menggunakan hak pilihnya (IDEA, 2014). Implikasinya, nyaris sulit menemukan fenomena abstention. Di Indonesia, abstention sering dikaitkan dengan istilah golput (Golongan Putih) yaitu mereka yang tidak menggunakan suara mereka untuk memilih kandidat atau partai dalam pemilu.

Meski terkesan memiliki definisi yang berbeda, protest voting dan abstention sebenarnya dua konsep yang dinamis dan sulit didemarkasi secara jelas. Pada kebanyakan kasus, justru keduanya bisa saling terkait. Dalam arti, tindakan protes pemilih bisa dituangkan dalam bentuk abstein, dan abstein dalah bagian dari protes itu sendiri. Singkatnya, ketidakpuasan pemilih dapat dituangkan dalam bentuk protest voting atau abstention. Dua konsep ini menjadi bagian yang tidak bisa dilepaskan dari kajian voters turnout karena akan berimplikasi pada seberapa besar presentase pemilih yang datang ke tempat pemungutan suara dan seberapa besar pemilih yang tidak menggunakan suara mereka.

Tidak hanya soal kekecewaan dan ketidakpuasan pemilih terhadap pilihan yang tersedia dalam pemilu, ada beberapa hal yang dapat menjelaskan fenomena protest voting dan abstention secara khusus dan dinamika voter turnout secara general. Misalnya, protest voting dan abstention dipicu karena hadirnya distrust terhadap sistem politik yang ada, termasuk pada lembaga pemerintah dan partai politik. Selain itu, pemilih merasa tidak ada koneksi antara hasil pemilu dan perubahan kebijakan (Franklin, 1999:206).

Berbekal konsep tersebut, artikel ini ingin melihat bagaimana protest voting dan abstantion berkerja dalam konteks pilkada calon tunggal yang mengkontestasikan antara pasangan calon dengan kotak kosong. Keberadaan kotak kosong memberi warna baru dalam politik elektoral, sebab jika sebelumnya pemilih yang tidak puas dan kecewa terhadap pilihan yang ada cenderung memilih untuk abstein (golput). Tetapi sejak kotak kosong 
diperkenalkan, ia dapat menjadi pilihan alternatif sebagai simbol ekspresi politik atas ketidakpuasan pemilih terhadap kandidat secara spesifik dan secara general terhadap partai, pemerintah atau sistem politik yang ada.

\section{Metode Penelitian}

Artikel ini menggunakan metode penelitian kualitatif deskriptif. Pengumpulan data dilakukan melalui studi literatur terhadap sejumlah bahan bacaan yang relevan baik berasal dari buku, jurnal, media online dan sebagaimana. Data yang telah terkumpul selanjutnya dipilah dan diorganisasi oleh peneliti untuk mengambil data tertentu yang dianggap mampu menjawab kebutuhan pada penelitian ini. Proses ini menjadi penting untuk melakukan analisa data. Selanjutnya, data yang sudah dipilah disajikan baik dalam bentuk tabel, gambar atau berupa narasi dan deskripsi.

\section{Pembahasan}

\section{Calon Tunggal versus Kotak Kosong: Awal Mula Kemunculannya}

Pilkada serentak yang diselenggarakan pertama kali pada tahun 2015 sempat mencuri perhatian banyak pihak menyusul situasi dimana beberapa daerah hanya memiliki satu pasangan calon. Undang-undang nomor 8 tahun 2015 tentang Pemilihan Kepala Daerah yang berlaku saat itu mensyaratkan bahwa Pilkada dapat dilaksanakan paling sedikit dua pasangan calon. Problemnya, dari 269 daerah yang melaksanakan Pilkada, terdapat 11 daerah yang hanya memiliki satu pasangan calon. Mengantispasi hal tersebut dikeluarkan Peraturan KPU No 12 tahun 2015 yang menyebut bahwa KPU berhak melakukan perpanjangan pendaftaran calon apabila di daerah tertentu hanya terdapat satu pasangan calon. Apabila setelah waktu penambahan ini tidak juga menambah calon pasangan, maka Pilkada harus ditunda pada periode selanjutnya. Setelah melalui perpanjangan, terdapat tiga daerah yang masih memiliki satu pasangan calon yaitu, Kabupaten Timor Tengah Utara, Kabupaten Blitar dan Kabupaten Tasikmalaya.

Berhasilnya beberapa daerah menambah pasangan calon yang sebelumnya hanya memiliki satu pasangan calon menuai pertanyaan besar. Mengapa mayoritas partai politik yang sebelumnya terkonsentrasi pada dukungan terhadap salah satu pasangan calon dapat berpindah haluan keluar 
dari barisan koalisi dengan mendukung pasangan calon alternatif. Studi Nurprojo (2016) mengungkap bahwa hadirnya calon pasangan lain pada saat KPU melakukan masa perpanjangan pendafataran tidak lepas dari konspirasi elit partai agar Pilkada tidak ditunda. Implikasinya, calon pasangan lain yang muncul adalah calon boneka yang direkayasa sedemikian rupa agar seolahseolah terdapat kontestasi minimal dua pasangan calon. Kendati demikian, tidak menutup kemungkinan bahwa di beberapa daerah dengan adanya tambahan perpanjangan waktu sangat dimanfaatkan oleh aktor politik lokal untuk melakukan kembali konsolidasi sehingga memunculkan calon pasangan alternatif.

Tiga daerah yang masih memiliki satu pasangan calon berada dalam ketidakpastian. Merespon hal tersebut, MK mengeluarkan keputusan Nomor 100/PUU-XIII/2015 yang menetapkan bahwa daerah yang memiliki satu pasangan calon tetap melaksanakan pemilihan dengan mekanisme referendum. Pemilih dihadapkan dengan pilihan "Ya" dan "Tidak" terhadap pasangan calon tunggal yang tertera di kertas suara. Keputusan MK dianggap sebagai upaya untuk memenuhi hak politik warga negara untuk memilih dan dipilih (Dhesinta, 2016). Hadirnya keputusan MK yang membolehkan Pilkada dengan satu pasangan calon telah mengubah rezim elektoral yang awalnya kental dengan nuasa kontestasi menjadi referendum. Hasil Pilkada menunjukan kemenangan mutlak pasangan calon tunggal di tiga daerah tersebut.

Berkaca pada Pilkada serentak 2015, pemerintah dan DPR melakukan revisi undang-undang tentang Pilkada dengan mengeluarkan UU nomor 10 tahun 2016 tentang pemilihan kepala daerah. Regulasi tersebut semakin memperkuat eksistensi pasangan calon tunggal dengan tetap melaksanakan Pilkada. Namun, terdapat perubahan mekanisme pemilihan, jika sebelumnya calon pasangan tunggal didesain seperti referandum dengan pilihan "Ya" dan "Tidak", regulasi terbaru mengkontestasikan antara calon tunggal dengan kotak kosong. Kotak kosong dihadirkan sebagai pilihan alternatif bagi pemilih yang tidak berkenan memilih pasangan calon.

Keberadaan kotak kosong dianggap sebagai upaya agar dimensi kontestasi tetap ada. Namun kontestasi tersebut sejatinya tidak benar-benar fair. Dominasi kekuasaan calon tunggal yang mayoritas adalah calon incumbent. Mereka ditopang oleh modal ekonomi dan politik yang besar sehingga membuat partai berbondong-bondong memberikan dukungan politik 
tanpa memunculkan calon alternatif lain untuk berlaga dalam panggung pilkada (Bawaslu, 2018; ). Partai dan elit politik sebagai aktor rasional tentu tidak akan membuang tenaga dan biaya yang sia-sia tanpa didasari kalkulasi kemungkinan menang dalam kontetasi politik. Akibatnya calon tunggal tidak memiliki hambatan yang berarti dalam dimensi persaingan dengan aktor lain dalam berebut kekuasaan apalagi bersaing dengan kotak kosong (Lay et al, 2017).

Selain itu, keberadaan regulasi juga turut menghambat hadirnya persaingan yang fair antara calon tunggal dan kotak kosong (Hikmania, 2018; Burhanuddin, 2018). Akibatnya terdapat dilema dalam tata kelola politik elektoral yang memunculkan pergulatan konsep pemilu antara contested election dan uncontested election. Dilema ini yang kemudian membuat ketidakjelasan dalam praktik pemilu dimana secara regulatif menghendaki adanya persaingan dalam pemilu yang diperkuat dengan adanya kotak kosong berhadapan dengan calon tunggal. Namun secara empiris, infrastruktur politik yang ada justru menciptakan uncontested election. Misalnya kotak kosong tidak memiliki anggaran, struktur kampanye dan mekanisme pengajuan sengketa yang tidak jelas.

Meskipun kotak kosong cenderung berada dalam pusaran uncontested election, tetapi keberadan kotak kosong menjadi alternatif pilihan politik bagi pemilih yang tidak setuju dengan figur dari calon kandidat. Dalam bentuk lain, kotak kosong menjadi simbol perlawanan masyarakat sipil atas banyak hal, misalnya kekecewaan dengan pasangan calon yang tersedia, ketidakpuasan terhadap sistem politik yang ada, dan bentuk kritik terhadap partai politik yang gagal dalam menghadirkan calon alternatif (Romli, 2018; Febrian, et al., 2019; Widyasari, 2019). Hal ini diperkuat dengan munculnya gerakan masyarakat sipil yang menggorganisir masa untuk kotak kosong dengan tujuan menjegal kemenangan pasangan calon. Misalnya, gerakan kotak kosong dapat di temukan di Kabupaten Pati, Kabupaten Enrekang, Kabupaten Lebak dan Kota Makassar. Meskipun gerakan kotak kosong ini masih sporadis dan lemah serta secara keseluruhan belum mampu mengalahkan calon kandidat, tetapi pengalaman di Kota Makassar cukup mencengangkan karena sebagai satusatunya daerah dengan pilkada yang memiliki calon tunggal namun dikalahkan oleh kotak kosong karena massifnya mobilisasi masyarakat sipil mengkampanyekan untuk memilih kotak kosong (Febrian, et al., 2019). 
Munculnya gerakan masyarakat sipil yang mengkampanyekan kotak kosong dan bukti kemenangan kotak kosong di Kota Makassar mempertegas bahwa kotak kosong sebagai bentuk perlawanan atau protest voting. Pemilih memilih kotak kosong dari pada calon kandidat dilandasi oleh ketidaksukaan mereka terhadap pilihan yang ada dalam Pilkada.

\section{Membaca Voters Turnout Pada Pilkada Serentak 2018}

Kontestasi elektoral di tingkat lokal tidak bisa lepas dari isu tentang calon tunggal dan kotak kosong. Hal ini berangkat dari fakta empiris bahwa keberadaan calon tunggal sangat pontensial yang jumlanya terus bertambah setiap periode pilkada. Pada pilkada serentak 2015 jumlah daerah yang memiliki calon tunggal sebanyak 3 daerah. Sedangkan pada pilkada serentak 2017 bertambah menjadi 9 daerah. Eksistensi calon tunggal tidak bisa dibendung pada pilkada berikutnya, dimana sebanyak 16 daerah mengkontestasikan antara calon tunggal dan kotak kosong pada pilkada 2018.

Selain karena jumlah calon tunggal lebih tinggi, pada pilkada serentak 2018 mencatat sejarah baru dimana kotak kosong mampu memenangkan calon tunggal meski hanya ditemukan di Kota Makassar. Kendati demikian, jika ditelusuri lebih detail bagaimana partisipasi pemilih akan terlihat bahwa kotak kosong memiliki daya tawar politik yang cukup signifikan sebagai penantang pasangan calon. Perhatikan tabel berikut:

Tabel 1. Perolehan Suara Pasangan Calon dan Kotak Kotak Kosong

Pada Pilkada Serentak 2018

\begin{tabular}{|c|c|c|c|c|c|c|c|c|c|c|}
\hline \multirow[b]{2}{*}{ No } & \multirow[b]{2}{*}{ Kabupaten/Kota } & \multirow{2}{*}{$\begin{array}{c}\text { Jumlah } \\
\text { Hak Pilih } \\
\text { (DPT) }\end{array}$} & \multicolumn{4}{|c|}{ Perolehan Suara } & \multicolumn{4}{|c|}{ Tingkat Partisipasi } \\
\hline & & & $\begin{array}{c}\text { Pasangan } \\
\text { Calon }\end{array}$ & $\%$ & $\begin{array}{c}\text { Kotak } \\
\text { Kosong }\end{array}$ & $\%$ & Kehadiran & $\%$ & $\begin{array}{l}\text { Tidak } \\
\text { Hadir }\end{array}$ & $\%$ \\
\hline 1 & Kab.Jayawijaya & 268.416 & 260.012 & $99,13 \%$ & 2.271 & $0,87 \%$ & 263.750 & $98,26 \%$ & 4.666 & $1,74 \%$ \\
\hline 2 & Kota Tangerang & 1.051 .272 & 609.428 & $85,62 \%$ & 102.386 & $14,38 \%$ & 723.104 & $68,78 \%$ & 328.168 & $31,22 \%$ \\
\hline 3 & Kab.Tangerang & 1.867 .011 & 941.804 & $83,72 \%$ & 183.095 & $16,28 \%$ & 1.148 .762 & $61,53 \%$ & 718.249 & $38,47 \%$ \\
\hline 4 & Kab.Tapin & 128.608 & 85.826 & $80,88 \%$ & 20.278 & $19,12 \%$ & 111.117 & $86,40 \%$ & 17.491 & $13,60 \%$ \\
\hline 5 & Kab.Deli Serdang & 1.165 .769 & 538.238 & $82,25 \%$ & 116.193 & $17,75 \%$ & 720.096 & $62 \%$ & 445.673 & $38 \%$ \\
\hline 7 & $\begin{array}{l}\text { Kab.Padang Lawas } \\
\text { Utara }\end{array}$ & 148.394 & 86.915 & $80,13 \%$ & 21.559 & $19,87 \%$ & 113.405 & $76,42 \%$ & 34.989 & $23,58 \%$ \\
\hline 7 & Kota Prabumulih & 130.206 & 74.723 & $79,26 \%$ & 19.552 & $20,74 \%$ & 96.702 & $74,27 \%$ & 33.504 & $25,73 \%$ \\
\hline 8 & Kab.Pasuruan & 1.151 .502 & 536.721 & $77,55 \%$ & 155.393 & $22,45 \%$ & 769.715 & $66,84 \%$ & 381.787 & $33,26 \%$ \\
\hline 9 & Kab.Lebak & 929.567 & 453.938 & $76,96 \%$ & 135.879 & $23,04 \%$ & 608.538 & $65,46 \%$ & 321.029 & $34,54 \%$ \\
\hline 10 & Kab.Enrekang & 149.115 & 77.586 & $67,15 \%$ & 35.826 & $31,03 \%$ & 115.444 & $77,42 \%$ & 33.671 & $22,58 \%$ \\
\hline
\end{tabular}


158 Mahpudin Protest Voting dan Abstention..

\begin{tabular}{|c|l|r|r|r|r|r|r|r|r|r|}
\hline 11 & $\begin{array}{l}\text { Kab.Minahasa } \\
\text { Tenggara }\end{array}$ & 81.531 & 47.499 & $67,28 \%$ & 23.098 & $32,72 \%$ & 71.382 & $87,55 \%$ & 10.149 & $12,45 \%$ \\
\hline 12 & Kab.Bone & 534.510 & 232.961 & $62,95 \%$ & 137.136 & $37,05 \%$ & 387.000 & $72,40 \%$ & 147.510 & $27,60 \%$ \\
\hline 13 & Kab.Mamasa & 114.048 & 48.552 & $61,22 \%$ & 30.758 & $38,78 \%$ & 80.279 & $70,39 \%$ & 33.769 & $29,61 \%$ \\
\hline 14 & Kota Makassar & 1.021 .714 & 264.245 & $46,77 \%$ & 300.795 & $53,23 \%$ & 584.406 & $57,20 \%$ & 437.308 & $42,80 \%$ \\
\hline
\end{tabular}

Sumber: Diolah oleh peneliti dengan merujuk data dari KPU RI tahun 2020

Tabel diatas menjelaskan bahwa dari 14 kabupaten/kota sebanyak 7 daerah dengan perolehan kotak kosong dibawah 20 \%, yaitu Kab. Jayawijaya, Kota Tangerang, Kab. Tangerang, Kab. Tapin, Kab. Deli Serdang, dan Kab. Padang Lawas Utara. Sisanya, sebanyak 7 daerah dengan perolehan kotak kosong diatas $20 \%$. Terkait dengan tingkat partisipasi pemilih terbilang cukup tinggi diatas $60 \%$, kecuali Kota Makasar dengan tingkat partisipasi pemilih hanya 57,20 \%. Perolehan suara kotak kosong ditempatkan sebagai bentuk protest voting sebab pemilih memilih kotak kosong karena tidak menghendaki terpilihnya pasang calon tunggal.

Sementara, jika mengacu pada data pemilih yang tidak menggunakan hak pilihnya atau abstein, tidak sampai menyentuh pada angka $50 \%$. Namun, apabila dikomparasikan dengan masing-masing daerah didapati bahwa mayoritas daerah (10 dari 14 daerah) presentase jumlah pemilih yang tidak hadir ke TPS lebih besar dibandingkan dengan presentase jumlah pemilih kotak kosong. Empat daerah lainnya (Kab. Jayawijaya, Kab. Patin, Kota Prabumulih, Kab. Minahasa) presentase jumlah suara kotak kosong lebih tinggi dibandingkan dengan presentase jumlah pemilih yang tidak datang ke TPS. Dengan kata lain, dapat dikatakan bahwa jumlah pemilih yang abstein ratarata jauh lebih tinggi dari pada pemilih dengan protest voting.

Dari tabel diatas, jika merujuk pada pembacaan data terkait partisipasi pemilih, maka dapat dilihat bahwa eksistensi pasangan calon tunggal masih dominan dan sulit dikalahkan oleh kotak kosong. Hal ini dapat dilihat dari 13 daerah kecuali Kota Makassar, dimenangkan oleh pasangan calon. Kemenangan pasangan calon tunggal sangat wajar sebab dalam aturan mengatur bahwa pasangan calon dinyatakan menang dengan perolehan suara mayoritas dari jumlah suara sah. Regulasi yang ada saat ini tidak mengatur batasan tertentu berapa jumlah suara sah atau jumlah partisipasi pemilih sebagai indikator untuk menyatakan kemenangan kandidat. Artinya, berapapun jumlah suara sah dari partisipasi pemilih yang datang ke TPS, dijadikan sebagai indikator untuk kemenangan calon, terlepas apakah 
partisipasi pemilih rendah atau tinggi.

Sebagai ilustrasi, misalnya partisipasi pemilih yang datang ke TPS hanya $10 \%$ dari jumlah daftar pemilih tetap (DPT). Dari $10 \%$ partispasi pemilih, sebanyak $8 \%$ suara sah dan suara tidak sah sebesar $2 \%$. Dari $8 \%$ suara sah, $5 \%$ memilih pasangan calon dan 3\% memilih kotak kosong. Dalam aturan pemilu yang ada, maka pasangan calon tampil sebagai pemenang mengalahkan kotak kosong karena berhasil memperoleh suara mayoritas meski hanya $5 \%$ dari $8 \%$ suara sah. Padahal, jika menghitung angka perolehan, kemenangan tersebut sangat rendah. Artinya, apabila mengacu pada pendapat yang menyatakan bahwa pemilu sebagai proses pemberian legitimasi formal kepada pemerintah terpilih, maka ketika kandidat yang tampil sebagai pemenang tidak mampu mendapatkan simpati atau dukungan mayoritas keseluruhan masyarakat di daerah yang bersangkutan, dapat dikatakan legitimasi yang diperoleh adalah legitimasi semu. Inilah logika demokrasi prosedural, dimana makna demokrasi tereduksi hanya sebatas hitung-hitungan angka. Padahal, jika mencermati data partisipasi pemilih, belum tentu kandidat yang menang mendapatkan legitimasi dan kepercayaan publik secara substansial.

Hal tersebut paling tidak nampak dalam kontestasi antara pasangan calon dan kotak kosong. Meski dari permukaan nampak bahwa pasangan calon lebih unggul dibandingkan kotak kosong, tetapi apabila ditelaah lebih komprehensif, beberapa daerah yang berhasil memenangkan pasangan calon tunggal tidak benar-benar unggul mutlak. Dalam kaitan ini, penulis mencoba membandingkan antara perolehan suara pasangan calon dengan jumlah suara di luar pasangan calon yang diperoleh dari hasil kalkulasi antara suara kotak kosong (protest voting) dan jumlah pemilih yang tidak datang ke TPS (abstention). Perhatikan tabel berikut.

Tabel 2. Perbandingan perolehan Suara Pasangan Calon dan Non Pasangan Calon

\begin{tabular}{|c|c|c|c|c|c|}
\hline \multirow[b]{2}{*}{ No } & \multirow[b]{2}{*}{ Kabupaten/Kota } & \multirow{2}{*}{$\begin{array}{c}\text { Pasangan } \\
\text { Calon }\end{array}$} & \multicolumn{3}{|c|}{ Jumlah Suara diluar Paslon } \\
\hline & & & $\begin{array}{l}\text { Protest } \\
\text { Voting }\end{array}$ & Abstention & Jumlah \\
\hline 1 & Kab.Deli Serdang & 538.238 & 116.193 & 445.673 & 561.866 \\
\hline 2 & Kab.Tapin & 85.826 & 20.278 & 17.491 & 37.769 \\
\hline 3 & Kota Prabumulih & 74.723 & 19.552 & 33.504 & 53.056 \\
\hline
\end{tabular}




\begin{tabular}{|r|l|r|r|r|r|}
\hline 4 & Kab.Pasuruan & $\mathbf{5 3 6 . 7 2 1}$ & 155.393 & 381.787 & $\mathbf{5 3 7 . 1 8 0}$ \\
\hline 5 & Kab. Padang Lawas & $\mathbf{8 6 . 9 1 5}$ & 21.559 & 34.989 & $\mathbf{5 6 . 5 4 8}$ \\
\hline 6 & $\begin{array}{l}\text { Kab.Minahasa } \\
\text { Tenggara }\end{array}$ & $\mathbf{4 7 . 4 9 9}$ & 23.098 & 10.149 & $\mathbf{3 3 . 2 4 7}$ \\
\hline 7 & Kab. Bone & $\mathbf{2 3 2 . 9 6 1}$ & 137.136 & 147.510 & $\mathbf{2 8 4 . 6 4 6}$ \\
\hline 8 & Kab. Enrekang & $\mathbf{7 7 . 5 8 6}$ & 35.826 & 33.671 & $\mathbf{6 9 . 4 9 7}$ \\
\hline 9 & Kota Makassar & $\mathbf{2 6 4 . 2 4 5}$ & 300.795 & 437.308 & $\mathbf{7 3 8 . 1 0 3}$ \\
\hline 10 & Kab. Mamasa & $\mathbf{4 8 . 5 5 2}$ & 30.758 & 33.769 & $\mathbf{6 4 . 5 2 7}$ \\
\hline 11 & Kab. Jayawijaya & $\mathbf{2 6 0 . 0 1 2}$ & 2.271 & 4.666 & $\mathbf{6 . 9 3 7}$ \\
\hline 12 & Kab. Lebak & $\mathbf{4 5 3 . 9 3 8}$ & 135.879 & 321.029 & $\mathbf{4 5 6 . 9 0 8}$ \\
\hline 13 & Kab.Tangerang & $\mathbf{9 4 1 . 8 0 4}$ & 183.095 & 718.249 & $\mathbf{9 0 1 . 3 4 4}$ \\
\hline 14 & Kota Tangerang & $\mathbf{6 0 9 . 4 2 8}$ & 102.386 & 328.168 & $\mathbf{4 3 0 . 5 5 4}$ \\
\hline
\end{tabular}

Sumber: Diolah oleh peneliti dengan merujuk data dari KPU RI tahun 2020

Tabel diatas menjelaskan bahwa apabila perolehan suara pasangan calon dikomparasikan dengan jumlah perolehan suara hasil akumulasi antara perolehan suara kotak kosong (protest voting) dan jumlah pemilih yang tidak hadir ke TPS (abstention), maka sebanyak 6 kabupaten/kota menunjukkan perolehan suara pasangan calon lebih rendah dibandingkan dengan protest voting dan abstention. Data ini mengindikasikan bahwa dibalik kemenangan pasangan calon terdapat divergensi realitas politik utamanya terkait dinamika partisipasi pemilih dalam hal protest voting dan abstention. Artinya, kita dapat mempertanyakan kembali ide legitimasi formal yang berdiri atas klaim suara mayoritas. Padahal, apabila dikaji lebih jauh klaim suara mayoritas hanya berdasar pada suara sah saja bukan berdasar pada keseluruhan daftar pemilih yang ada di daerah yang bersangkutan. Dengan kata lain, merujuk pada 6 daerah tersebut dapat dikatakan bahwa perolehan suara protest voting dan abstention jauh lebih unggul dibandingkan dengan perolehan suara pasangan calon. Kemenangan pasangan calon berdiri di atas pondasi legitimasi yang relatif rendah. 


\section{Identifikasi Kepentingan yang Diwakilkan Mempertegas Makna Protest Voting dan Abstention: Sebuah Perdebatan}

Artikel ini menempatkan protest voting sebagai bentuk lain dari perolehan suara kotak kosong yang berdasar pada logika hadirnya ketidakpuasaan dan kekecewaan publik terhadap pasangan calon. Sementara abstention adalah pemilih yang abstein (golput) ditandai dengan ketidak hadiran di TPS. Mereka menarik diri dari pemilihan dengan tidak memilih pasangan calon tunggal atau pun kotak kosong. Namun, protest voting dan abstention sebenarnya bersifat cair. Pada satu sisi, keduanya dapat dibedakan secara tegas, namun di sisi lain sering ditemukan kesulitan untuk menentukan garis demarkasi antara keduanya.

Kang (2004) misalnya mencoba mengurai pertautan antara voting protest dan abstention bahkan voter turnout secara general dengan spesifik pada konteks negara-negara yang menggunakan sitem pemilu plural atau majoritaran yang sangat membatasi pilihan pemilih untuk menentukan partai yang beragam sesuai dengan preferensi dan kepentingan mereka. Konsekuensinya, pemilih mungkin memilih partai atau kandidat yang ada bukan berdasarkan pilihan alamiah mereka tetapi karena tidak ada alternatif pilihan lainnya. Dalam kondisi yang berbeda, pemilih mungkin dapat mengambil langkah protest voting dengan memilih partai lain diluar preferensi partai utama mereka dengan tujuan memberikan sinyal kekecewaan terhadap partai yang menjadi pilihan mereka. Atau pemilih dapat melakukan abstention karena tidak puas dengan sistem pemilu plural. Singkatnya, terdapat dilema dalam sistem pemilu plural dimana pemilih memilih abstein atau tetap memilih meskipun tidak puas dengan pilihan yang ada. Artinya, pemilih yang menunggunakan hak pilihnya bisa jadi karena terpaksa sebab tidak ada altenatif pilihan lain, atau mereka sama sekali menarik dari pemilihan.

Meminjam logika berfikir tersebut, jika dikaitkan dengan konteks Pilkada calon tunggal sangat memungkinkan bahwa kemenangan pasangan calon secara mayoritas di daerah yang mengkontestasikan antara calon tunggal dan kotak kosong bukan berarti masyarakat puas dengan pilihan pasangan calon yang tersedia, tetapi karena tidak ada alternatif pilihan lain ditengah ketidakpastian kemenangan kotak kosong. Hal ini berangkat dari logika uncontested election yang selolah-olah menghadirkan kontestasi antara pasangan calon dan kotak kosong tetapi secara empiris kontestasi tersebut 
tidak fair karena kotak kosong tidak memiliki payung hukum yang kuat, basis dukungan yang solid, dan tidak ditopang oleh modal ekonomi dan politik yang memadai sehingga sulit untuk mengalahkan dominasi kekuasaan pasangan calon yang ditopang oleh dukungan ekonomi dan politik yang signifikan. Implikasinya, hanya satu saja yang berhasil memenangkan kotak kosong yaitu di Kota Makkasar sementara sisanya semua daerah dimenangkan pasangan calon.

Meskipun tidak menutup kemungkinan bahwa pasangan calon yang tampil sebagai pemenang dikarenakan pasangan calon tersebut memiliki prestasi dan dianggap mampu untuk menjadi kepala daerah. Artinya pemilih menyukai dan tertarik terhadap pasangan calon. Tetapi tidak menutup kemungkinan bahwa beberapa pasangan calon yang berhasil memenangkan kontestasi elektoral melawan kotak kosong bukan bararti pasangan calon tersebut disukai oleh pemilih. Argumen ini berdasar pada data yang ditampilkan pada pembahasan sebelumnya dimana jika melihat presentase hitung-hitungan angka terkait voter turnout, kemenangan pasangan calon di enam daerah pada Pilkada serentak 2018 lebih rendah perolehan suaranya apabila dikomparasikan dengan hasil kalkulasi perolehan suara antara protest voting (memilih kotak kosong) dan abstention (pemilih yang tidak datang ke TPS). Sementara, bentuk protest voting yang paling nyata dapat ditemukan pada Pilkada Kota Makassar yang mampu memenangkan kotak kosong.

Pilihan terhadap kotak kosong dapat dengan mudah diletakkan sebagai bentuk protes voting, tidak sama halnya dengan abstention. Tindakan pemilih menarik diri dari kegiatan pemilihan (voting) dengan tidak mendatangi TPS dapat diidentifikasikan oleh banyak hal. Abstention bisa diletakkan sebagai bentuk protest voting karena kecewa dengan opsi pilihan yang ada. Mereka tidak puas dengan pasangan calon dan disaat yang bersamaan ragu dengan kotak kosong karena merasa bahwa kotak kosong sulit menang dan tidak yakin apakah kotak kosong mampu menghadirkan pemimpin alternaif yang lebih baik dari pasangan calon. Pemilih menilai bahwa tanpa datang ke TPS, pemenangnya sudah dapat ditentukan yaitu pasangan calon. Karena itu, pilihan untuk tidak datang ke TPS adalah keputusan politik terbaik.

Hal ini nyaris serupa dengan fenomena abstention (golput) di masa rezim otoriterianisme Soeharto. Menjelang pemilu 1971, sekelompok masyarakat sipil pro demokrasi meproklamirkan gerakan golput sebagai bentuk 
protes terhadap rezim Soeharto yang gagal dalam membangun kesejahteraan masyarakat. Saat itu, pemilu hanya sebatas legitimasi formal bagi Soeharto untuk berkuasa. Pemilu telah didesian sedemikian rupa sehingga hasil pemilu sudah bisa ditentukan pemenangnya, yaitu Golkar, kendaraan politik Soeharto. Sementara, partai alternatif yang menjadi peserta pemilu yaitu PDI dan PPP mustahil memenangkan pertarungan. Karena itu, aktivis pro demokrasi memandang bawha Golput adalah pilihan politik terbaik. Pada masa orde baru, Golput (abstention) adalah simbol perlawanan dan bentuk protes rakyat terhadap penguasa (Nyarwi, 2009).

Meskipun patut juga diperhatikan bahwa abstention tidak selalu terkait dengan dimensi politik yang menjelaskan hadirnya kritik dan protes pemilih terhadap pemilu. Abstention bisa karena faktor non ideologis, misalnya kecenderungan pemilih yang apatis-apolitis, memiliki halangan di hari pemilihan seperti urusan pekerjaan, sakit, dan sebagainya. Karena itu, membaca fenomena abstention (golput) perlu diletakkan pada dua perspektif, yaitu abstention sebagai gerakan politik dan sebagai perilaku pemilih (Nyarwi, 2009). Sebagai gerakan politik, asbtention dilakukan baik oleh kelompok yang bersaing dalam kontestasi politik ataupun kelompok yang merasa kecewa dan termarginalkan dari proses politik. Sedangkan sebagai perilaku pemilih, abstention sebagai sikap dari para pemilih terkait pilihan mereka dengan beragam alasan, yaitu alasan ideolgis maupun non ideologis.

Dalam konteks Pilkada satu pasangan calon, gerakan masyarakat sipil yang mmperjuangkan kemenangan kotak kosong sangat berkontribusi secara efektif dalam menghasilkan perolehan suara kotak kosong sebagai protest voting atau minimal membuat pemilih memilih untuk abstein. Kemenangan kotak kosong di Makkasar tidak lepas dari hadirnya gerakan kotak kosong yang memobilisasi pemilih untuk tidak memilih pasangan calon (Bawaslu, 2019). Begitu pula di daerah lainnya, meski tidak sampai mengalahkan pasangan calon, tetapi perolehan suara kotak kosong cukup signifikan. Misalnya di Kabupaten Pati pada pilkada 2017 mampu memperoleh suara sebanyak 25 \% lebih tidak lepas dari kehadiran AKDPP (Aliansi Kawal demokrasi Pilkada Pati) (Widyasari, et al., 2019; Darmawan, 2017), Pilkada di Kabupaten Lebak pada tahun 2018 dengan perolehan kotak kosong sebanyak $23 \%$ adalah buah perjuangan politik gerakan BAJUKOKO (Barisan Juang Kotak Kosong). Artinya, sangat terbuka peluang bagi kemenangan kotak kosong apabila dua kondisi terpenuhi. 
Pertama, terdapat kekecewaan publik dan di saat yang bersamaan kekecewaan tersebut dimobilisasi secara massif oleh gerakan kotak kosong sehingga banyak warga yang terlibat dan terarik untuk memilih kotak kosong. Kedua, desain pilkada yang mengatur soal kotak kosong secara institusi harus diperkuat oleh payung hukum untuk menciptakan contested election yang fair. Apabila dua kondisi ini terpenuhi, tidak menutup kemungkinkan akan ada daerah lain yang mampu memenangkan kotak kosong, tidak hanya di Kota Makasar.

\section{Kesimpulan}

Tulisan ini menujukkan bahwa partispasi pemilih dalam konteks pilkada dengan satu pasangan calon memiliki dinamika politik tersendiri, khususnya hadirnya protest voting yang termanifestasikan lewat kotak kosong dan abstention dalam bentuk ketidakhadiran pemilih di TPS. Pilkada serentak 2018 dengan satu pasangan calon semuanya dimenangkan oleh pasangan calon, hanya satu daerah yaitu Kota Makassar yang berhasil memenangkan kotak kosong.

Meskipun mayoritas daerah dimenangkan oleh pasangan calon, tetapi apabila dilihat dari perolehan suara secara detail menunjukkan di 5 daerah (Kab.Deli Serdang, Kab.Pasuruan, Kab. Bone, Kab. Mamasa, Kab. Lebak) presentase kemenangan pasangan calon rendah dibandingkan dengan presentase perolehan suara akumulasi dari protest voting dan abstention. Hal ini merefeleksikan bahwa tidak semua pasangan calon yang menang ditopang oleh basis legitimasi yang kuat. Sangat dimungkinkan pada 5 daerah tersebut kemenangan pasangan calon bukan karena masyarakat puas dengan kinerja pemerintahan yang ada, tetapi karena tidak ada alternatif pilihan lain ditengah ketidakpastian kemenangan kotak kosong.

Karena itu, eksistensi kotak kosong perlu diperkuat dengan menyediakan payung hukum yang memadai agar logika contested election terasa nyata sehingga kotak kosong bukanlah sekedar simbol tanpa makna yang terpajang di kertas suara. Kotak kosong dapat menjadi alternatif pilihan politik masyarakat yang tidak puas dengan pasangan calon yang ada. Memperkuat eksistensi kotak kosong menjadi penting agar tujuan pemerintah tetap menghadirkan dimensi kontestasi dan partisipasi tidak sekedar iluminasi 
semata. Demokrasi elektoral minimal harus ditopang oleh dua hal, yaitu kontestasi dan partisipasi (Dahl, 1973). Menjadi tidak berguna kita membicarakan bagaimana partisipasi pemilih dalam pilkada dengan satu pasangan calon apabila dimensi kontestasi yang bekerja saja tidak fair, hanya menguntungkan pasangan calon dibandingkan kotak kosong. Sebab apabila partisipasi tinggi namun kontestasi rendah maka sistem politik yang tercipta adalah 'hegemoni inklusif'. Padahal, tentu kita mengharapkan hadirnya kontestasi dan partisipasi yang tinggi sehingga menjadi dasar terciptanya iklim demokrasi atau dalam bahasa Dahl disebut "Poliarki".

\section{DAFTAR PUSTAKA}

Bawaslu. (2018). Fenomena Calon Tunggal, Studi Kasus pada Pilkada 2018 di 16 Kabupaten/Kota. Jakarta: Bawaslu RI

Burhanuddin. (2019). Kotak Kosong Dalam Rezim Pemilihan Kepala Daerah. Jurisprudentie, Vol 5 No 1 (Hal 64-73).

Dahl, Robert. (1973). Polyarchy: Participation and Opposition. United State: Yale University Press

Darmawan, I. (2017). Peran Dan Strategi Kelompok "Kotak Kosong" Dalam Pilkada Calon Tunggal Kabupaten Pati Tahun 2017: Studi Pendahuluan. Jurnal Wacana Politik, Vol. 2, No. 1, 45 - 51

Delwit, P. (2013). The End of Voters in Europe? Electoral Turnout in Europe since WWII; Journal of Political Science Vol 3. No. 1Hikmania, Y. S. (2018). Pergulatan Konsep Contested Election dan Uncontested Election (Studi Kasus Pilkada Kabupaten Pati Tahun 2017). Tesis. Tidak Diterbitkan. Fakultas IImu Sosial dan Ilmu Politik. Yogyakarta: Universitas Gadjah Mada.

Dhesinta, Wafia. S. (2016). Calon Tunggal Dalam Pemilihan Umum Kepala Daerah Dan Konsep Demokrasi (Analisis Terhadap Pemilihan Kepala Daerah Kabupaten Blitar Tahun 2015). Jurnal Cita Hukum, Vol 4 No 1. DOI: $10.15408 /$ jch.v4i1.2578 
Febrian., Rumesteran, I., Apriyani, L. (2019). An Analysis of Defeated Single Candidate of Indonesia's Simultaneous Regional Elections 2018. Advances in Social Science, Education and Humanities Research, volume 363

Franklin, M. N. (1999). Electoral engineering and cross-national turnout differences: What role for compulsory voting?. British Journal of Political Science, 29, 205-224. doi:10.1017/S0007123499210095

International IDEA. (2016). Voter Turnout Trends around the World. Stockholm: International IDEA

Kang, W. T. (2004). Protest Voting and Abstention under Plurality Rule Elections. Journal of Theoretical Politics, Vol 16 No 1.

Komisi Pemilihan Umum RI. (2020). Online. Diakses dari: https:www.kpu.go.id. Kselman, D \& Niou, E. (2014). Protest Voting in Plurality Elections: A Theory of Voter Signaling. DOI: $10.1007 /$ s11127-010-9661-2

Lay, C., Hanif, H., Ridwan, \& Rohman, N. (2017). The Rise of Uncontested Elections in Indonesia: Case Studies of Pati and Jayapura. Contemporary Southeast Asia, 39(3), 427-448. Retrieved March 9, 2020, from www.jstor.org/stable/44684049

Nurprojo, Indaru. S. (2016). Bagongan, Pilkada Serentak dan Demokrasi yang Cedera: Belajar dari Purbalingga. Politik Indonesia: Indonesian Political Science Review 1 (2), 120-135

Nyarwi. (2009). Golput Pasca Orde Baru: Merekonstruksi Ulang Dua Perspektif. Jurnal Ilmu Sosial dan Ilmu Politik, Vol 12, No 3, 257-390.

Romli, Lili. (2018). Pilkada Langsung, Calon Tunggal dan Masa Depan Demokrasi Lokal. Jurnal Penelitian Politik, Vol (15) No 2.

Rosenstone, Steven J., Roy L. Behr, and Edward H. Lazarus. (1996). Third Parties in America. Citizen Response to Major Party Failure. Princeton University Press: Princeton.

Widyasari, A, Reyke, dan Vierra. (2019). Gerakan Politik Pendukung Kotak Kosong: Keterlibatan Civil Society dalam Pilkada Kabupaten Pati Tahun 2017. Jurnal Polgov, Vol 1, No 1. 